\title{
Knowledge and attitudes of community pharmacists about COVID-19
}

\author{
Nilay AKSOY ${ }^{1 *}$ (D) Öyküm DEMİREL ${ }^{1}$ (D) \\ 1 Department of Clinical Pharmacy, Faculty of Pharmacy, Altınbaş University, Bakırköy, İstanbul, Turkey. \\ * Corresponding Author. E-mail: nilay.aksoy@altinbas.edu.tr (N.A.); Tel. +90-0 2127094528.
}

Received: 12 July 2021 / Revised: 09 October 2021 / Accepted: 15 October 2021

\begin{abstract}
Since the outbreak of Coronavirus Disease 2019 (COVID-19), it has been considered an emergency situation that requires community pharmacists to be involved in direct patient care. The goal of this study is to collect information on community pharmacists' knowledge, attitudes, practices, and educational initiatives and pandemic preparedness, as well as to analyze challenges that may faced during the pandemic. Questionners from previous literature were used after translation and validation in a pilot study. Google forms were used to distribute the questionners to all the community pharmacies in Çanakkale, Turkey after ethic approval from Altınbaş University ethic committee. There were a total of 40 open-ended questions prepared to test knowledge attitudes presented as multiple choice or Likert scale questions. SPSS 20 software programme was used to analyze data. Among the all pharmacies, 60 pharmacists from 60 pharmacy were participated in the study. $70 \%$ of those who took part in the study were women, and $30 \%$ were between the ages of 40 and 49 . The mean score of knowledge based questions were $9.85 / 13$, the majority of pharmacists were worried about being contaminated or infecting their families and were following the safety rules. The participants had certain gaps in their pandemic preparedness. To conclude, pharmacists have a moderate level of understanding of COVID-19 related topics, sufficient information about the pandemic, and they are strong enough to deal with the resulted obstacles. Although there are significant gaps and problems, the shortcomings can be solved by providing proper motivation and training to increase awareness.
\end{abstract}

KEYWORDS: COVID-19; community pharmacists; knowledge; attitude; preparedness; practices.

\section{INTRODUCTION}

Starting with the reporting of unknown cause pneumonia cases in Wuhan, Hubei Province of China on 17th of November 2019, COVID-19 has spread globally and has been recognized by the WHO as the largest global epidemic in the 21st century, causing many deaths. COVID-19 is considered as a relative of the serious acute respiratory syndrome (SARS) and Middle East Respiratory Syndrome (MERS).

The disease is caused by SARS-CoV-2 beta-coronavirus that is the ribonucleic acid (RNA) virus, which affects the lower respiratory tract resulting in human pneumonia [1,2]. The elderly population or people with morbidities like diabetes, hypertension, cardiovascular disease was suffered from more severe symptoms according to the healthy young patients [3].

The rapid spread of the Coronavirus Disease 2019 (COVID-19) called for a mass movement of all medical workers, including pharmacists, who play an important role as they are the first contact line with the patients who still do not know yet the dangers of the spreading virus [3]. In addition, it is clear that pharmacists play an important role in preventing information pollution, reducing the sense of fear in society, directing people to take precautions without panic, and decreasing the load on hospitals. For all these reasons, it was very important for pharmacists to have detailed information about the virus from the symptoms to diagnosis, spreading methods, recommended therapies, and identified preventive measures [4,5].

The study aimed to collect information on community pharmacists' knowledge, attitudes, and practices, as well as educational initiatives and pandemic preparedness, as well as to analyze challenges that may be faced during the pandemic.

\section{RESULTS}

The study included a total of 60 pharmacists from 60 different pharmacies in Çanakkale, Turkey with a response rate of $38 \%$. Females were present in a high participation number according to the male $(70 \% \mathrm{n}=60)$.

How to cite this article: Aksoy N, Demirel Ö. Knowledge and attitudes of community pharmacists about COVID-19. J Res Pharm. 2021; 25(6): 905-912. 
The most participated age group in this study was between $40-49$ years old $(25 \%, n=60)$ while the education level was divided by three Bachelor's, Master's and PhD's Degree and The Bachelor's Degree was $81.7 \%$ while the Master's Degree rate was $18.3 \%$. When examined in terms of years of experience, the majority of pharmacists were own 25 years of experience or more $(43.3 \%, n=60)$. More than a quarter of the pharmacists who participated in the study said that their first source of information and news about the virus were their colleagues $(36.7 \%)$ while $(66.7 \%)$ of the pharmacist were checking the new updates of COVID-19 'once daily. Furthermore, the vast majority of the participated pharmacists were thinking that COVID-19 will end in 1-2 years $(48.3 \%, \mathrm{n}=60)$. The mean score of knowledge-based questions was 9 out of 13 . Table 1 shows the questions, their correct answers, and the number of pharmacists answered correctly.

Table 1. The knowledge's level about COVID-19 among pharmacists.

\begin{tabular}{|c|c|c|c|}
\hline \multirow[t]{2}{*}{ Knowledge -Based Questions } & \multirow[t]{2}{*}{ Answers } & \multicolumn{2}{|c|}{$\begin{array}{l}\text { Number and percentage } \\
\text { of pharmacist answered }\end{array}$} \\
\hline & & $\mathbf{N}$ & $\%$ \\
\hline \multirow{2}{*}{$\begin{array}{l}\text { The official name announced for the virus responsible for the } \\
\text { disease COVID-19 is 'Severe acute respiratory Syndrome } \\
\text { Coronavirus-2'. }\end{array}$} & True $^{*}$ & 46 & 76.7 \\
\hline & False & 14 & 23.3 \\
\hline \multirow{4}{*}{ Declared COVID-19 a Pandemic } & China & 5 & 8.3 \\
\hline & $\mathrm{ABD}$ & 6 & 10.0 \\
\hline & FIP & 1 & 1.7 \\
\hline & $\mathrm{WHO}^{*}$ & 48 & 80.0 \\
\hline \multirow{4}{*}{ The incubation period of COVID-19 } & 2-7 days & 21 & 35.0 \\
\hline & 2-14 days* & 37 & 61.7 \\
\hline & 7-14 days & 2 & 3.3 \\
\hline & 7-21 days & 0 & 0 \\
\hline \multirow{4}{*}{ The most common symptom of COVID - $19 ?$} & Fever, cough & 7 & 11.7 \\
\hline & Fatigue & 3 & 5.0 \\
\hline & Shortness of breath & 0 & 0 \\
\hline & All of the above* & 50 & 83.3 \\
\hline \multirow{4}{*}{ COVID-19 transmission occurs through } & Air & 4 & 6.7 \\
\hline & Contact & 0 & 0 \\
\hline & Fecal-Oral & 0 & 0 \\
\hline & $\begin{array}{l}\text { All of the above* } \\
\text { Pneumonia }\end{array}$ & 56 & 93.3 \\
\hline Complications of COVID-19? & $\begin{array}{l}\text { Respiratory failure } \\
\text { Death } \\
\text { All of the above* }\end{array}$ & 0 & 0 \\
\hline What is the mortality rate from COVID-19? & $\begin{array}{l}0-1 \% \\
1.1-5 \% * \\
5.1-10 \% \\
10.1-25 \\
>25 \%\end{array}$ & $\begin{array}{l}7 \\
29 \\
18 \\
6 \\
0\end{array}$ & $\begin{array}{l}11.7 \\
48.3 \\
30.0 \\
10.0 \\
0\end{array}$ \\
\hline \multirow{4}{*}{$\begin{array}{l}\text { Are there FDA approved antibiotics for treating COVID-19 } \\
\text { patients? } \\
\text { Could COVID-19 infection manifest as diarrhea, vomiting, } \\
\text { gastrointestinal upset? }\end{array}$} & Yes & 5 & 8.3 \\
\hline & $\mathrm{No}^{*}$ & 55 & 91.7 \\
\hline & Yes* & 56 & 93.3 \\
\hline & No & 4 & 6.7 \\
\hline Could COVID-19 infection occur as neurological symptoms? & $\begin{array}{l}\text { Yes* } \\
\text { No }\end{array}$ & $\begin{array}{l}38 \\
22\end{array}$ & $\begin{array}{l}63.3 \\
36.7\end{array}$ \\
\hline \multirow{4}{*}{ How to reduce the risk of transmission? } & $\begin{array}{l}\text { By hand hygiene } \\
\text { Covering the nose and } \\
\text { mouth when coughing }\end{array}$ & $\begin{array}{l}0 \\
0\end{array}$ & $\begin{array}{l}0 \\
0\end{array}$ \\
\hline & Avoiding contact with & 4 & 6.7 \\
\hline & patients Having well- & $\begin{array}{l}4 \\
0\end{array}$ & 0 \\
\hline & $\begin{array}{l}\text { cooked meat and eggs } \\
\text { All of the above * }\end{array}$ & 56 & 93.3 \\
\hline \multirow{3}{*}{$\begin{array}{l}\text { Which of the below products are you recommending to patients } \\
\text { to disinfect? }\end{array}$} & Alcohol 50\% & 0 & 0 \\
\hline & Alcohol 70\%* & 54 & 90.0 \\
\hline & Alcohol 10\% & 6 & 10.0 \\
\hline In hospitals and pharmacies, all surfaces that may be & Ethanol (75\%) & 0 & 0 \\
\hline contaminated with the virus must be sterilized. All of the & Chlorhexidine* & 7 & 11.7 \\
\hline following can be used in the sterilization process, with the & Peracetic acid & 17 & 28.3 \\
\hline exception for & Chloroform & 36 & 60.0 \\
\hline
\end{tabular}

* Correct answers 
Cronbach's Alpha value is 0.544 for all the Likert scale questions. The majority of pharmacists (54 out of 60) were worried about being infected or passing the infection to their families and 26 of them reported feeling depressed. Furthermore, thirty-five pharmacists reported that stress had no effect on the quality of their work during the pandemic. Table 2 explains the frequency of the answer related to the attitude based questions.

Table 2. Attitude based questions about COVID-19.

\begin{tabular}{lcccc}
\hline \multicolumn{1}{c}{ Attitude based Questions } & \multicolumn{3}{c}{ Frequency } & \\
& Never & Rarely & Sometimes & Always \\
\hline Afraid of getting infected with COVID-19 & 9 & 9 & 10 & 32 \\
Afraid your family members getting infected & 1 & 4 & 1 & 54 \\
Feeling depressed/exhausted & 26 & 10 & 16 & 8 \\
Are stress feelings affecting your duties & 35 & 9 & 10 & 6 \\
Does any of your staff declare wanting to leave work? & 47 & 10 & 3 & 0 \\
\hline
\end{tabular}

Most of the pharmacists have joined the COVID-19 education ceremonies knowing how to educate the patients about the symptoms, signs, and mode of transmission, preventative measures and risks. The educative based questions about COVID-19 is explaines in Table 3.

Table 3. Educative based questions about COVID-19.

\begin{tabular}{lcccc}
\multicolumn{1}{c}{ Educative based Questions } & \multicolumn{3}{c}{ Frequency } \\
& Never & Rarely & Sometimes & Always \\
\hline $\begin{array}{l}\text { Do you educate about the risk of COVID-19? } \\
\text { Do you educate about the symptoms, signs, and mode of }\end{array}$ & 0 & 1 & 7 & 52 \\
transmission of COVID-19? & & 0 & 12 & 48 \\
Do you educate about the preventative measures of COVID-19? & 0 & 0 & 12 & 48 \\
Do you advise the patients to avoid public gatherings & 0 & 2 & 11 & 49 \\
Do you educate the patients about the importance of handwashing & 0 & 47 \\
\hline
\end{tabular}

All of the pharmacists were following the safety rules especially using the masks but there were some different opinions about the usage of safety goggles and gloves. Table 4 explaines the answer frequency related to the practice based Questions.

Table 4. Practice based questions about COVID-19.

\begin{tabular}{lcccc}
\multicolumn{1}{c}{ Practice based Questions } & \multicolumn{4}{c}{ Frequency } \\
& Never & Rarely & Sometimes & Always \\
\hline Using a mask at the pharmacy? & 0 & 0 & 0 & 60 \\
Using gloves at the pharmacy? & 43 & 3 & 9 & 0 \\
Wearing goggles at the pharmacy? & 50 & 10 & 0 & 0 \\
Maintaining social distancing? & 0 & 6 & 4 & 50 \\
Did the working hours decrease? & 38 & 8 & 11 & 3 \\
\hline
\end{tabular}

The participants had some gaps in preparing for the pandemic. Such as reading articles about COVID19 , reading guidelines, participating in educational activities. The Pandemic preparedness based questions about COVID-19 is explained in table 5. The relationships between sociodemographic information, attitude, preparedness, educational activities and application scores were investigated with the Kruskal-Wallis test. All the demographic variables is explained in table 6.

\section{DISCUSSION}

COVID-19 is a global pandemic that has affected individuals of all ages and sectors without discrimination [4]. Pharmacists are the first-line responders for COVID-19 affected person care [3, 6]. Frontline healthcare workers have an 11.6 times higher risk of being tested positive than the general population, according to analysis [7]. The outcomes of our research show that healthcare workers are not only at the forefront of COVID, but also increasing awareness that they are in the most risky group in all health-related issues. Between 2003 and 2015, people affiliated with health institutions accounted for 44-100 percent of SARS and MERS incidents, with healthcare staff accounting for roughly one-quarter of those infected [8]. 
Table 5. Pandemic preparedness based questions about COVID-19.

\begin{tabular}{lccc}
\multicolumn{1}{c}{ Pandemic preparedness Questions } & \multicolumn{2}{c}{ Frequency } \\
\multicolumn{1}{c}{ Sometimes } & Always \\
\hline $\begin{array}{l}\text { Knowing all the relevant (national and international } \\
\text { information maintaining the best pharmaceutical care) }\end{array}$ & 19 & 6 & 21 \\
$\begin{array}{l}\text { Reading general guidance about COVID-19 (for example; } \\
\text { National, WHO or CDC COVID-19 guidance). }\end{array}$ & 2 & 8 & 28 \\
Reading medical articles & 6 & 13 & 22 \\
Participating in educational activities & 13 & 10 & 14 \\
Knowing FIP guidance & 13 & 10 & 21 \\
\end{tabular}

Table 6. The variability of questionnaire response among various demographic variables.

\begin{tabular}{|c|c|c|c|}
\hline QUESTIONS & Age & $\begin{array}{l}\text { P-VALUE } \\
\text { Years of } \\
\text { Experience }\end{array}$ & $\begin{array}{l}\text { Educational } \\
\text { Level }\end{array}$ \\
\hline $\begin{array}{l}\text { The distribution of 'Social media (Facebook, Twitter, } \\
\text { WhatsApp, YouTube, Instagram, Snapchat...)' is the } \\
\text { same across categories of ... }\end{array}$ & $.007^{*}$ & $.007^{*}$ & .354 \\
\hline $\begin{array}{l}\text { The distribution of 'Family member, colleague, or friend' } \\
\text { is the same across categories of ... }\end{array}$ & $.015^{*}$ & $.006^{*}$ & .496 \\
\hline $\begin{array}{l}\text { The distribution of 'The official name of COVID-19' is } \\
\text { the same across categories of ... }\end{array}$ & .046 & $.605^{*}$ & $.658^{*}$ \\
\hline $\begin{array}{l}\text { The distribution of 'Are there FDA approved antibiotics } \\
\text { for treating COVID-19 patients?' is the same across } \\
\text { categories of ... }\end{array}$ & .027 & .105 & $<.001^{*}$ \\
\hline $\begin{array}{l}\text { The distribution of 'Could COVID-19 infection occur as } \\
\text { neurological symptoms?' is the same across categories of } \\
\text {... }\end{array}$ & .459 & $.020^{*}$ & $.037^{*}$ \\
\hline $\begin{array}{l}\text { The distribution of 'Which of the below products are you } \\
\text { recommending to patients to disinfect?' is the same } \\
\text { across categories of ... }\end{array}$ & $.761^{*}$ & $.576^{*}$ & $.225^{*}$ \\
\hline $\begin{array}{l}\text { The distribution of 'Are you afraid your family members } \\
\text { get infected because of your occupational exposure?' is } \\
\text { the same across categories of ... }\end{array}$ & .398 & $.013^{*}$ & $.002 *$ \\
\hline $\begin{array}{l}\text { The distribution of 'Do you feel depressed/exhausted } \\
\text { due to the current pandemic?' is the same across } \\
\text { categories of ... }\end{array}$ & $.019 *$ & .448 & .518 \\
\hline $\begin{array}{l}\text { The distribution of 'Do you educate the patients and the } \\
\text { people around you about the preventative measures of } \\
\text { COVID-19.' is the same across categories of ... }\end{array}$ & $.003^{*}$ & $.043^{*}$ & .869 \\
\hline $\begin{array}{l}\text { The distribution of 'Do you wear goggles to protect your } \\
\text { eyes while performing your job at the pharmacy?' is the } \\
\text { same across categories of ... }\end{array}$ & .323 & .220 & $<.001^{*}$ \\
\hline $\begin{array}{l}\text { The distribution of 'Are you able to maintain social } \\
\text { distancing of at least } 1.5 \mathrm{~m} \text { from work colleagues?' is the } \\
\text { same across categories of ... }\end{array}$ & $.010^{*}$ & $.045^{*}$ & $.008^{*}$ \\
\hline $\begin{array}{l}\text { The distribution of 'I know all the relevant information } \\
\text { related to COVID-19 disease.' is the same across } \\
\text { categories of ... }\end{array}$ & .716 & .142 & $.030^{*}$ \\
\hline $\begin{array}{l}\text { The distribution of 'I know that the International } \\
\text { Pharmaceutical Federation (FIP) has issued a guidance } \\
\text { for COVID-19 related to pharmacists and the pharmacy } \\
\text { workforce?' is the same across categories of ... }\end{array}$ & .193 & .256 & $.003^{*}$ \\
\hline
\end{tabular}

As the world places a greater emphasis on limiting non-essential daily activities and services, pharmacies have become an ever more valuable source of medicines and healthcare advices [9]. There is an epidemic of misinformation resulting from the overabundance of information published by WHO, which is referred to as an "info-demic" in conjunction with the pandemic [10].

Furthermore, it is clear that pharmacists play an important role in preventing information pollution, reducing the sense of fear in society, directing people to take precautions without panic, and raising awareness 
about the importance of continuing their lives while taking precautions. As the number of COVID-19 positive cases continues to rise, pharmacists want precise and reliable information in order to appropriately educate the public.

As a consequence, pharmacists around the country must have a detailed understanding of the disease, from clinical symptoms to diagnosis, recommended therapies, and identified preventive measures [4]. Female participation was higher than male in our study, which could be due to the fact that women make up the majority of pharmacists in Canakkale.

The most participated age group in this study was between 40 - 49 years old while another study reported the mean age of the participants 20 to 40 [4, 11,12]. Pharmacists gave different answers to the questions according to their different ages, years of experience, and education level, the same results were observed as well in a study conducted by Bhagavathula et al [12].

In view of the source of the information, the majority of the participated pharmacists reported that the source of their information was their colleagues but in other studies, the majority of information sources were the official website and social media. [3, 4]. The reason for this difference could be due to the different age ranges and education levels of the participants $[4,10]$.

Asking participants 'How often do you check new updates on COVID-19?' In our study, the answer to the question was 'once daily' but according to the other published studies, the answers were more than once daily.[4-11-12]. As for the question of when the pandemic will end, almost half of the pharmacists answered 'within 1-2 years. In a study conducted in Turkey on the first days of the pandemic, the majority of the participants answered 'when the air temperature rises', or ' 6 months to 1 year'. Despite these predictions, the pandemic state continues and it still maintains its seriousness in Turkey and worldwide [13].

As a result of the research, It was concluded that the knowledge level of the pharmacists was good (9.85 out of 13 nearly $75 \%$ ). Parallel to this study, in a study done in Yemen, it was determined that the knowledge was sufficient (8 out of 9 nearly 88.8) [14]. For instance, another study conducted in China's Henan region discovered that around 89 percent of healthcare employees had enough knowledge [15]. In contrast, in Bagavethula et al.'s study, it was determined that healthcare workers had insufficient information [12]. The reason why this rate was low in our study can be shown as the pharmacists aren't following the guidelines published by FIP, CDC and WHO sufficiently.

When the pharmacists were asked about the fear that they can pass the infection to their families with COVID19 , the level of the fear was higher according to the results of the other studies $[4,10,11,12]$.

A study conducted in India's general population reported that approximately $80 \%$ of respondents had sleep difficulties and paranoia of getting infected [16] while in our study, anxiety and stress levels were much lower than in other studies $[4,10,11,12]$. This could be explained as the number of Covid-19 cases in Çanakkale was not very high from the beginning of the pandemic. However, after the date of the surveys, a rapid increase of cases has been shown in Çanakkale which could make a change in the anxiety and stress levels.

Participants of this research reported that there are still some misunderstanding issues from the population about the effective COVID-19 prevention in Çanakkale and it was underlined that correcting these misunderstandings requires proper education and awareness. For this purpose, the rules and measures to be followed for the protection of pharmacy staff are displayed on posters and warning signs. In our study, the contribution of pharmacists to education activities was high. In Al-Ashwal et al. study generally, they had very few responses as 'never or rarely' to educate their patients, parallel to our study [14]. In a study by Jalil et al., pharmacists had positive perceptions of their role during the COVID-19 pandemic, and only $7.2 \%$ of pharmacists reported not doing any activities. A small portion of them reported that they took more preventive actions before the epidemic spread. For example; Preparing educational videos, give seminars about the disease, and to produced alcohol-based disinfectants in their pharmacies [11].

FIP, CDC, WHO, and the Ministry of Health of the Republic of Turkey have all provided guidance since the outbreak began. Its contents are constantly changing as new guidelines are released. Pharmacists are expected to follow and be familiar with these guides, which will help with educational initiatives. According to our study, the number of pharmacists who always read the general guidelines on COVID-19 is 22 . The number of pharmacists who read medical articles all the time is still low, with only 14 pharmacists. In addition, only 13 pharmacists have never heard about the FIP guidelines.

In the study conducted in Yemen "where the questions were taken as the source", the results were slightly different. In addition, $56 \%$ of the participant's answers were "I have enough knowledge about COVID$19^{\prime \prime}$ and $84.6 \%$ of them had read general guidelines on COVID-19 from organizations such as WHO, CDC, and $67.3 \%$ were confident that they had sufficient knowledge of educating patients and community members 
about COVID. The important point was that $76.3 \%$ of the read articles were about being prepared for the COVID-19 pandemic [14].

In a study asked whether FIP knew 'COVID-19 guidelines for pharmacists and the pharmacy workforce', $56.4 \%$ answered no; $24.7 \%$ of them replied that they knew the guide but had no chance to read it [11]. When looking at the other studies, according to practice levels questions, it was discovered that while pharmacists pay close attention to put masks and follow the social distance restrictions, participants believe that using gloves more frequently at the start of the pandemic increases contamination later on. It was more advantageous to wash hands and use disinfectant than to use gloves, according to them $[3,4,15,17]$.

While the main concern was lack of preparedness in the other studies, in our study Some of the pharmacists mentioned that they believe that the information being published is not true and inaccurate [18].

The results of other studies about pandemic preparedness were also low in parallel with our study [4, $10,11,12]$. The shortcoming in this regard can be attributed to the excessive workload of pharmacists and their inability to find time for such activities. Given the rapidly changing nature of the COVID-19 pandemic and the frequency with which information changes, it is essential that healthcare professionals know where to use up-to-date guides. Conducting the survey electronically under COVID-19 measures was one of the restrictions, which can be explained by the lack of access to or participating in social platforms due to the busy workload of pharmacists.

The higher number of female participants may indicate that the interest of male participants is low, but it is also necessary to consider the high number of female pharmacists throughout the province. Another limitation was that the survey was conducted in Çanakkale and the surrounding districts, and it was applied only in the community pharmacy. This can be shown as a cause of the low number of participants.

As a result, proper pandemic preparedness training and current information should be arranged. The Ministry of Health and pharmacist chambers bear a significant amount of responsibility in this regard. Working procedures should be set up so that the first line of defense, pharmacy staff, has enough time to recover and avoid overwork and blunders while dealing with outbreaks.

\section{CONCLUSION}

Our study results concluded that the surveyed pharmacists have a moderate level of knowledge regarding COVID-19, enough to be transferred to their patients and have the strength to cope with the pandemic challenges and obstacles in which their attitude towards the pandemic is good. It has been found that there are some shortcomings and different thoughts regarding the management of the pandemic.

Health-care workers must ensure that they have continuous access to the most up-to-date data and that this information is properly transferred to practice.

Finally, the Circumstances of this study can be changed, but pharmacists' responsibility to inform and provide primary health care will not. As a result, knowing the fundamental perception and struggle techniques, as well as planning and being prepared, is critical.

\section{MATERIALS AND METHODS}

\subsection{Study design and procedure}

The ethical committee approval was obtained from Altinbas university preceding study commencement and the research was conducted with the help of voluntary pharmacies in Çanakkale center and its affiliated districts throughout research in June 2021.

All the pharmacists working in community pharmacies in Çanakkale were included in the study $(\mathrm{N}=158$ pharmacies). Pharmacists working in other settings or working outside of Çanakkale are excluded from this survey. Our analysis is a descriptive, cross-sectional observational study that was performed using Google online forms and an anonymous online questionnaire. To avoid potentially dangerous conditions during interviews due to the pandemic, the survey was circulated via social media platforms such as WhatsApp, Facebook or telephone calls.

\subsection{Survey development}

Survey questions were collected from different sources that translated to the Turkish language and validated in a small pilot study. [3-4-10-11-12-13-14-20]. The questionnaire was divided into 6 different parts, 
socio-demographic variables such as age, gender and duration of work were documented. Although there were a total of 40 open-ended questions prepared with multiple choice and Likert scale, the estimated time to answer the questions was around 5-10 minutes.

The questionnaire was divided into 6 parts: 1-7. questions related to socio-demographic characteristics (age, gender, duration of work (years)), 8-20. questions based on information, 21-25. questions were based on attitude, 26-30. questions were based on educational activities, 31-35. questions were based on practice and 36-40. questions were based on pandemic preparedness.

\subsection{Data management and statistical analysis}

For all statistical analysis, Statistical Package for the Social Sciences (SPSS) 20 was used. The 95\% confidence interval with $p<0.05$ was used to assess the results. The associations between sociodemographic knowledge, attitude, preparedness, educative activities, and practice scores were investigated. A p-value of less than 0.05 in the Kruskal-Wallis test is considered statistically significant. The volunteer consent form was placed on the first page of the questionnaire, in which participants were introduced to the study's goals and told that participation was voluntary, after which they were asked if they wanted to participate.

Acknowledgment: Nur Öztürk for her continuous support.

Author contributions: Concept - N.A., O.D.; Design N.A; Supervision - N.A.; Resources - O.D.; Materials - O.D.; Data Collection and/or Processing - O.D.; Analysis and/or Interpretation - N.A.; Literature Search - N.A, O.D Writing N.A, O.D.; Critical Reviews - N.A., O.D.

Conflict of interest statement: The authors declared no conflict of interest.

Ethics committee approval: Altinbas University Ethic Committee.Date of decision: 25.06.2021 Number: 67.

\section{REFERENCES}

[1] Pascarella G, Strumia A, Piliego C, Bruno F, Del Buono R, Costa F, Scarlata S, Agrò FE. COVID-19 diagnosis and management: a comprehensive review. J Intern Med. 2020; 288(2): 192-206. [CrossRef]

[2] Shereen MA, Khan S, Kazmi A, Bashir N, Siddique R. COVID-19 infection: Origin, transmission, and characteristics of human coronaviruses. J Adv Res. 2020; 24: 91-98. [CrossRef]

[3] Zeenny RM, Ramia E, Akiki Y, Hallit S, Salameh P. Assessing knowledge, attitude, practice, and preparedness of hospital pharmacists in Lebanon towards COVID-19 pandemic: a cross-sectional study. J Pharm Policy Pract. 2020; 13: 54. [CrossRef]

[4] Yimenu DK, Demeke CA, Kasahun AE, Asrade S, Mekuria AB. COVID-19: What should health professionals know? Assessment of Knowledge, attitude, and practice of community pharmacists in a developing country. SAGE Open Med. 2020; 8: 1-10. [CrossRef]

[5] Altıparmak Ö, Selçuk A, Rabuş Ş. COVID-19 Pandemisi ile Mücadelede Toplum Eczanelerinin Rolü. In: Işıldak AG. (Ed.), COVID-19 Mücadelesinde Türk Eczacıları Birliği., Türk Eczacıları Birliği Yayınları, Ankara, 2021, pp. 27-35.

[6] Hess K, Bach A, Won K, Seed SM. Community Pharmacists Roles During the COVID-19 Pandemic. J Pharm Pract. 2020; 1: 1-8. [CrossRef]

[7] Chan AT, Drew DA, Nguyen LH, Joshi AD, Ma W, Guo CG, Lo CH, Mehta RS, Kwon S, Sikavi DR, Magicheva-Gupta MV. The COronavirus Pandemic Epidemiology (COPE) consortium: a call to act]on. Cancer Epidemiol Biomarkers Prev. 2020;29(7):1283-1289. [CrossRef]

[8] Pala SÇ, Metintas S. COVID-19 Pandemisinde Sağlık Çalışanları. ESTÜDAM Halk Sağlı̆̆ı Dergisi. 2020; 5: 156-168. [CrossRef]

[9] FIP Call to action to support pharmacists and pharmacy workers on the coronavirus/COVID-19 frontline2020. https://www.fip.org/files/content/publications/2020/FIP-call-toaction-to-support (accessed on 20 April 2021).

[10] Paul G, Sharma S, Singh G, Singh G, Sharma S, Paul BS, Gautam PL. Assessment of knowledge gaps and perceptions about COVID-19 among health care workers and general public-national cross-sectional study. J Anaesthesiol Clin Pharmacol. 2020; 36(3): 337-344. [CrossRef]

[11] Jalil MA, Alsous MM, Hammour KA, Saleh MM, Mousa R, Hammad EA. Role of pharmacists in COVID-19 disease: a Jordanian perspective. Disaster Med Public Health Prep. 2020; 14(6): 782-788. [CrossRef] 
[12] Bhagavathula AS, Aldhaleei WA, Rahmani J, Mahabadi MA, Bandari DK. Knowledge and perceptions of COVID-19 among health care workers: cross-sectional study. JMIR Public Health Surveill. 2020; 6(2): e19160. [CrossRef]

[13] Emre KA, Demirkan K, Serhat ÜN. Knowledge and attitudes among hospital pharmacists about COVID-19. Turk J Pharm Sci. 2020; 17(3): 242-248. [CrossRef]

[14] Al-Ashwal FY, Kubas M, Zawiah M, Bitar AN, Mukred Saeed R, Sulaiman SA, Khan AH, Ghadzi SM. Healthcare workers' knowledge, preparedness, counselling practices, and perceived barriers to confront COVID-19: A crosssectional study from a war-torn country, Yemen. PloS one. 2020; 15(12): e0243962. [CrossRef]

[15] Zhang M, Zhou M, Tang F, Wang Y, Nie H, Zhang L, You G. Knowledge, attitude, and practice regarding COVID19 among healthcare workers in Henan, China. J Hosp Infect. 2020; 105(2): 183-187. [CrossRef]

[16] Roy D, Tripathy S, Kar SK, Sharma N, Verma SK, Kaushal V. Study of knowledge, attitude, anxiety \& perceived mental healthcare need in Indian population during COVID-19 pandemic. Asian J Psychiatr. 2020; 51: 102083. [CrossRef]

[17] Muhammad K, Saqlain M, Muhammad G, Hamdard A, Naveed M, Butt MH, Khan S, Ismael NS, Khan Z, Karatas Y. Knowledge, Attitude, and Practices (KAPs) of Community Pharmacists Regarding COVID-19: A Cross-Sectional Survey in 2 Provinces of Pakistan. Disaster Med Public Health Prep. 2021; 1-9.[CrossRef]

[18] Prescott K, Baxter E, Lynch C, Jassal S, Bashir A, Gray J. COVID-19: How prepared are front-line healthcare workers in England? J Hosp Infect. 2020; 105(2): 142-145. [CrossRef]

[19] Elhadi M, Msherghi A, Alkeelani M, Zorgani A, Zaid A, Alsuyihili A, Buzreg A, Ahmed H, Elhadi A, Khaled A, Boughididah T, Khel S, Abdelkabir M, Gaffaz R, Bahroun S, Alhashimi A, Biala M, Abulmida S, Elharb A, Abukhashem M, Elgzairi M, Alghanai E, Khaled T, Boushi E, Ben Saleim N, Mughrabi H, Alnafati N, Alwarfalli M, Elmabrouk A, Alhaddad S, Madi F, Madi M, Elkhfeefi F, Ismaeil M, Faraag B, Badi M, Al-Agile A, Eisay M, Ahmid J, Elmabrouk O, Bin Alshiteewi F, Alameen H, Bikhayr H, Aleiyan T, Almiqlash B, Subhi M, Fadel M, Yahya H, Alkot S, Alhadi A, Abdullah A, Atewa A, Amshai A. Assessment of Healthcare Workers' Levels of Preparedness and Awareness Regarding COVID-19 Infection in Low-Resource Settings. Am J Trop Med Hyg. 2020; 103(2): 828-833. [CrossRef]

[20] Zhong BL, Luo W, Li HM, Zhang QQ, Liu XG, Li WT, Li Y. Knowledge, attitudes, and practices towards COVID-19 among Chinese residents during the rapid rise period of the COVID-19 outbreak: a quick online cross-sectional survey. Int J Biol Sci. 2020; 16(10): 1745-1752. [CrossRef]

This is an open access article which is publicly available on our journal's website under Institutional Repository at http://dspace.marmara.edu.tr. 